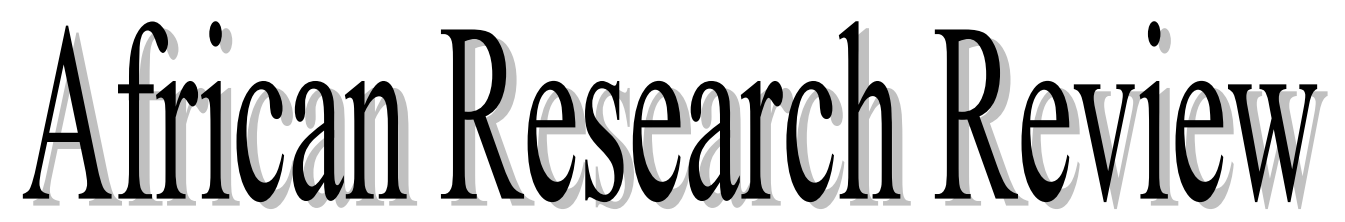

AN INTERNATIONAL MULTI-DISCIPLINARY JOURNAL, BAHIR DAR, ETHIOPIA

AFRREV VOL. 11 (4), SERIAL NO. 48, SEPTEMBER, 2017:174-185

ISSN 1994-9057 (Print)

ISSN 2070-0083 (Online)

DOI : http://dx.doi.org/10.4314/afrrev.v11i4.14

\title{
Exploring the Psychological Influence of Perceived Negative Foreign Factors on Organisational Performance and National Development
}

\author{
Ogunkuade, Idowu M. \\ Director, Nigerian Copyright Institute \\ Nigerian Copyright Commission, Abuja, Nigeria \\ E-mail: idowukuade@yahoo.com
}

\begin{abstract}
This paper critically examined the psychological influence of perceived negative foreign factors which were those obstacles brought to Nigeria and Nigerians since our first contact with the European colonialists. The obstacles have constituted formidable barriers to indigenous organisational performance and national development in Nigeria. Some of the foreign factors perceived to have paralysed, jeopardised and destroyed the economic fabric of Nigeria include colonialism, neo-colonialism, imported technology, debt trap peonage and a host of others. The consequences of these factors on workers' performance in Nigerian organisations, its effect on national development and the strategies for solving the problems were treated in this paper.
\end{abstract}

Key Words: European colonialists, foreign factors, psychological influence, indigenous organisational performance, national development

\section{Introduction}

The conduct of research on the well-being of the developing countries like Nigeria is not only important for individual nations but also for mutual global economic survival. According to Ogbuagu (1995), some researchers opined that the poor economic state of many third world countries is largely self-induced. For this reason, these researchers argue that it is irrelevant to suggest that the continuing prosperity and advancement of the economies of the centre nations may be threatened or jeopardised by the worsening conditions in the periphery states. Yet to others, the underdevelopment of the third world countries is as a result of past and continuing domination and exploitation by the developed nations (Fanon, 1963; Rodney, 1972).

Copyright () International Association of African Researchers and Reviewers, 2006-2017:

www.afrrevjo.net.

Indexed African Journals Online: www.ajol.info 
No nation can develop without the development of its workforce, which translates to effective and efficient performance of workers in its public and private organisations. In view of this, Ogunkuade (2016) opined that there is a need for harmonious workplace environment for workers' effectiveness and efficiency. It is therefore obivious from his opinion that a push for good behaviour within the workplace can contribute positively to creating a productive and harmonious environment in which workers can be inspired to achieve their full potentials. According to Gboyega (2003), development implies improvement in the material well-being of all citizens, not the most powerful and rich alone; but it also demands that poverty and inequality of access to the good things of life by both the rich and poor be removed or drastically reduced. It seeks to improve personal physical security and livelihoods and expansion of life chances. As reviewed in the work of Lawal and Abe (2011), development is viewed as a process of societal advancement where improvement in the well-being of people is generated through strong partnerships between all sectors inclusive of corporate bodies and other groups in the society. It is concluded that development is not only an economic exercise; it also involves both socio-economic and political issues and pervades all aspects of societal life. Drawing from these and more definitions of development, National Development can be described as the overall development or a collective socioeconomic, political as well as religious advancement of a country or a nation. It is also pertinent to say that there will be no reasonable national development without effective and efficient workers and organisational performance. There is therefore a strong link between workers' performance, organisational performance and national development.

What is performance? Performance can be defined as both physical and intellectual resources which a worker can offer in order to contribute to the progress of the organisation. There are some basic requirements which must be met if an organisation is to achieve maximum results from her employees. According to Schein (1965), those requirements include: Having a set of central goals or objectives towards which the organisation is striving; these objectives must be communicated down the line, with the idea of getting commitment and agreement regarding their value, reasonableness and feasibility; functional areas, departmental units and individuals must also have specific goals to attain; and the interdependence of all the sub units, within the organisation, to accomplish results must be clearly established while a frame work and climate for inter-unit cooperation must exist. Similarly, the strategic roles and contributions of the individuals must be specifically pinpointed and recognised. Mitchell's (1967) works on performance in organisation reveal that worker satisfaction produces effective organisational performance. He proposes that satisfaction causes high productivity. Workers' performance in organisation can be measured through: high profit, high productivity and value added. Any nation with effective workforce is most likely to achieve national development. Despite all efforts for national development, there are some perceived negative foreign factors that have constituted barriers to the well-being of a nation like Nigeria.

\section{Perceived Negative Foreign Factor}

Perceived negative foreign factors which is the theme of this paper, are those obstacles which were brought to Nigeria and Nigerians since our first contact with the European colonialists, which have successfully operated formidable barriers to indigenous

Copyright () International Association of African Researchers and Reviewers, 2006-2017: www. afrrevjo.net.

Indexed African Journals Online: www.ajol.info 
organisational performance and national development in Nigeria (Eze, 1984). Some of these perceived negative foreign factors that have paralysed, jeopardised and destroyed the economic fabric of Nigeria include colonialism, neo-colonialism, imported technology, debt trap peonage and the likes. Before the examination of these factors, it is pertinent, for better understanding of the topic, to review the local historical factors that influence workers' performance in Nigeria.

\section{The Local Historical Factors that Negatively Influence Workers' Performance in Nigeria}

The brutal colonisation of Nigerians by the Europeans, which has created and still creates a lot of impediments to the performance of workers in Nigeria, was caused by some militating historical factors of foreign dominations. These historical factors otherwise known as the internal factors are the root cause and origin of the multifarious perceived negative foreign factors adversely affecting workers' performance in Nigeria till date.

This paper viewed these internal factors as the root cause of the perceived negative foreign factor domination. The historical factors are obstacles to achieving effective development of Nigeria's organisation and national development. They are the indicators of underdeveloped intelligence in Nigeria. We have to know at this juncture that developed intelligence is the only weapon with which man or woman seeks and finds the truth, gains knowledge about the universe and discovers the secretes and laws of nature. It enables man or woman to create, innovate and invent, to master his/her environment and perform better on his/her job. Some of these internal factors are:

\section{Illiteracy}

Before the coming of the Europeans to Africa in the $18^{\text {th }}$ century, the entire black Africans did not know how to read or write; they were all illiterates grouping under a loose oral tradition. It was a mental and intellectual darkness; meaning that the then black Africans were intellectually blind or backward. According to UNESCO (2015), about 41 percent of Nigerians are still illiterates, with 69.2 percent male literacy rate and 49.7 percent female literacy rate. There is a saying that illiteracy is a disease, and the disease is intellectual in nature. Nigerians are still suffering from the native effects of intellectual disease and it has much negative impact on the workers' performance and adverse effect on national development.

\section{Inability to master our environment}

This is a conspicuous indicator of underdeveloped intelligence generating among the black Africans. The extent to which a given society can conquer and master its environment and adequately control its environmental resources constitutes the most reliable and valid measure of its intellectual development and maturity. Right from the ancestral era to the present time, our environment has remained unexplored and unconquered. Our land mass and soils contain huge deposits of minerals, oil and other natural resources, yet we have not shown any interest in tapping these resources. Natural wealth in water and space are also yet to be explored. Nigeria's over dependence on crude oil of all other existing mineral resources is worrisome. Today, these natural resources in our environment are still waiting for us. We depend on other

Copyright () International Association of African Researchers and Reviewers, 2006-2017: www.afrevjo.net.

Indexed African Journals Online: www.ajol.info 
countries for exploitation of our natural resources, for our organisation upbringing and this has a negative effect on the workers' performance.

\section{Failure to develop basic science and technology}

The inability of Nigeria and Nigerians to date to develop their own basic science and indigenous technology, and to establish their own genuine scientific and technological base, clearly shows a negative influence on workers' performance. This is because most of the technology used in Nigerian organisations are imported technology which our Nigerian workers know little or nothing about.

\section{Failure to develop an inquiring mind}

Nigerians' traditional indifference to scientific inquiry and knowledge seeking is primarily due to our ancestral failure to develop an inquiring mind with all its characteristics; scientific curiosity and risk-taking, and doubling and investigative attitudes. This failure is both a sign of an underlying intellectual weakness, and a cause of intellectual underdevelopment which have influenced worker's performance negatively till date.

\section{Poverty}

The inception and continued existence of poverty in Nigeria have jeopardised workers' performance. Nigerians' unabated level of intellectual poverty, financial poverty and moral poverty shows that we have not yet developed the required level of intelligence that can be applied to conquer different types of poverty facing the country and improve our living condition.

\section{Leadership, management and control inabilities}

Nigerians are known for leadership inability, management inability and control inability. These three related inabilities have been demonstrated by Nigerians in the past and present, in the discharge of their duties. These inabilities reflect the existence of some intellectual malfunctioning in the performance of our workers in Nigeria. In a nut shell, all these internal obstacles can be categorised as Ancestral obstacles, Cultural obstacles, Environmental obstacles and Psychological weaknesses (Eze, 1981), which have led to undue domination by our colonial master which is termed in this paper as foreign factors or external factors.

\section{Foreign Factors that Affect Workers' Performance in Nigeria}

Foreign factors otherwise known as the external factors as earlier defined in this paper are those obstacles which were brought to Nigeria since our first contact with the European colonialists, which have successfully operated formidable barriers to indigenous organisational performance and national development in the country. This discourse shall lay emphasis on those perceived negative foreign factors and how they affect organisational performance and national development in Nigeria. The foreign factors include but are not limited to the following:

\section{Colonialism}

Colonialism is a systematic domination, exploitation and control of a weak society by the stronger ones. Nigeria for example, suffered and is still suffering from the worst forms of both colonialism and colonisation, which include mental, physical and cultural

Copyright (C) International Association of African Researchers and Reviewers, 2006-2017: www.afrevjo.net.

Indexed African Journals Online: www.ajol.info 
colonisation. Nigerians sold their brothers and sisters as slaves to unknown foreign agents, who shipped them to Europe and America and were treated like animals. Today, Nigerians are still selling themselves to foreign nations. The agents connive with their foreign partners, act as fronts and loyalists to the foreign agents to defraud and exploit their native land in the name of human trafficking and working in foreign countries. The effects of this dehumanising behaviour of some Nigerians are very negative most especially in the area of national development.

\section{Neo-colonialism}

In the case of colonialism, the Colonisers used direct control and manipulation i.e. they were present to control physically, but in the Neo-Colonialism system, the Colonisers are out but they use remote control to colonise Nigerians. The remote controls include multinational companies, intelligence agencies, loyalist natives, religion, International Monetary Fund (IMF) and World Bank. For the purpose of this paper, multinational companies as a remote control is discussed below.

Multinational companies constitute a handful percent of all the organisations in Nigeria. In fact, this group of companies controls the national economy of Nigeria most especially in the areas of telecommunication, engineering and construction, and oil and gas. Over the years, the structure and successful performance of this group of companies have created a misleading picture of companies which are perceived as national organisations but which by the nature of their objectives and interest, are indeed foreign organisations. Some of the multinational companies include the oil and gas companies, food companies, assembly plants, mining industries, the big religious denominations, tobacco companies, breweries etc. Leadership styles and policies of these companies and organisations in one way or the other hamper workers' performance. Furthermore, the business and national interest of these multinationals have led to serious capital flight, which is detrimental to our national development.

\section{Imported Technology}

Technology pertains to the science and art of producing and distributing economic goods and services (Stanley, 1959). It is synonymous with organisation know-how and refers to the manner in which the available means of production are utilised. In a more technical term, John (1972) viewed technology as the "collective instruments" used by the operators to do their work.

Most of the technologies used in Nigerian organisations today are imported technologies. The consequence sometimes is low productivity and ineffectiveness among the workers due to lack of adequate knowledge of the technology. The life span of imported industrial equipment in Nigeria is low, the break down is frequent and the rate at which imported spare parts are used up is high. From these problems, we can conclude that there will be high consumption of spare parts, shortage of skilled technical manpower, lack of maintenance awareness at all levels and lastly absence of maintenance strategy.

A careful analysis of these problems will show that: the commonly invoked but widely misunderstood concept called "transfer of technology" can never take place as long as our expatriate technical experts continue to hide their technology secrets from Nigerians; both the equipment and the spare parts exported to Nigeria are sometimes

Copyright $\odot$ International Association of African Researchers and Reviewers, 2006-2017: www. afrrevjo.net.

Indexed African Journals Online: www.ajol.info 
inferior and built not to last long. Consequently, there is frequent importation and unending repairs or replacement of bad spare parts. Unfortunately, the Nigerian engineers' ignorance of how to maintain the imported technology and the keeping of technology secrets by expatriate technical experts, have encouraged the monopoly of expatriate engineers over the handling of their own equipment, thereby preventing the indigenous engineers from ever discovering the jealously guided secrets. Imported equipment most especially enhances injuries and accidents in an organization, and this has a great negative effect on workers' performance and national development.

\section{Creditor-debtor relationship (Debt trap peonage)}

Decades of serving as a colonial possession, borrowing heavy sums of money, accepting aids and grants by Nigeria on the one hand, and corresponding decades of providing regular loans and aids and controlling the economic destiny of the country by Western colonial nations on the other, have definitely created a creditor debtor relationship and a debt trap peonage system in which Nigeria becomes the peon, the labourer, the debtor and the host, while the Western colonial nations become the master, the employer, the creditor and all in all. In order to consolidate the relationship and the debt trap system, the Western nations developed the Brenton Woods economic Policies which culminated in the establishment of the IMF and its activities, allied joint objectives, allied joint actions and individual creditor's control activities. It is not in doubt that effective national organisations and national development may never be achieved as long as these objectives are being pursued and as long as these activities are being performed. Chinweizu (1984), viewed that one of the ploys that made Nigeria fall into the debt trap peonage was her being duped into believing that development can be bought, transferred, and installed on her land and that technology can be transferred.

\section{Foreign dominations and protectionism}

The fact that the economy of Nigeria is today dominated and controlled by foreign agents from other races is an indication of the existence of an underlying intellectual weakness in us. Often, foreign ideas and strategies such as Structural Adjustment Programme (SAP), Second-tier foreign exchange market (SFEM), World Bank's directives and IMF conditionalities and prescriptions are summarily imposed on Nigeria who pretends to possess the necessary information and desired level of intellectual development to implement the strategies successfully. Consequently, Nigeria has no other choice than to swallow the hard pills simply because she is psychologically and economically not free.

Foreign protectionism on the other hand, is the activities aimed at protecting the economic interests of the creditor nations. They include pursuing protectionist and monopolistic policies in the debtor countries, taking punitive counter-actions against a deviating or offending debtor, evading favours and leakage of information or secrets to debtor countries and vigilantly monitoring any deviations or escape plans by the peons.

\section{Borrowing and assembling economy}

The orthodox strategies of Nigerian organisations opt for buying, rather than working creatively into development. They were taught to hurry and buy up everything all at once, at all costs, instead of building up at a sure and steady pace. But Nigerian

Copyright $\odot$ International Association of African Researchers and Reviewers, 2006-2017: www. afrrevjo.net.

Indexed African Journals Online: www.ajol.info 
organisations are poor and chronically short of the only kind of payment which the seller of these things will accept. So, they go to their only available money lender to borrow money so that they can use it to purchase these products. All these attitudes have negative consequences on workers' performance and national development.

\section{Consequences of Foreign Factors on Workers' Performance and National Development}

As a result of negative effect of foreign factors on inhabitants of Nigeria, new sets of inhibitive factors known as the resultant factors or obstacles emerged. These factors are the consequences of perceived negative foreign factors on workers' performance and national development. In fact, these consequences are negative in all their ramifications. These consequences or resultant factors include the following.

\section{- Absence of self-awareness and self-identity}

Colonialism, neo-colonialism and the colonisation of Nigeria have jointly worked to make the citizens develop colonial, foreign and international mentalities, and in the process of doing this, they literally rejected themselves, their culture, religion and their human worth. The common behavioural disposition exhibited by Nigerians are selfabnegation, self-denial and identification with the western oppressors.

\section{- Chronic fear and white phobia}

Nigerian traditional chronic fear of risks, threats and lack of inquiring mind are alarming and worrisome. Also, Nigerians have excessive neurotic fear of their former white colonial masters and their allies, to such an extent that they are afraid to say or do anything which may antagonise them and their policies even if it is detrimental to her organisational performance and national development. It is this neurotic fear that has weakened the nation's psyche, imprisoned her intelligence, and rendered her leadership and management ineffective which have negative consequences on her workers' performance and national development.

\section{- Excessive religiosity}

Some Nigerians practise excessive religion. People who are fanatically religious are likely to be intellectually ineffective. Their thinking and reasoning is often controlled by religious dogma; they live by faith, hope and belief, and they are generally indifferent to the scientific pursuit of knowledge (Eze, 1981). In Nigeria of today, the rate at which churches and mosques are established out-numbers the establishment of industrial organisations. According to Okogie (2017), "despite the multiplicity of churches and mosques in Nigeria, there is still so much corruption, hunger, disease, poverty, unemployment, wickedness, witchcraft and frightening man's inhumanity to man in the country. Notwithstanding the array of churches and mosques, the country is dominated by morally bankrupt people and leaders. Nigerians spend too much of their time praying and running to churches and mosques, instead of working. This is why Nigeria remains a third-world country. He continued, countries dominated by religious zealots hardly develop. In Nigeria, churches and mosques buy premises of failed factories and convert them to churches and mosques which according to him is neoslavery. We should be talking about building cottage industries, schools and health centres on every street, instead of churches and mosques" Clearly, an attendant catalogue of failures, disappointments and frustrations often leads the individual to

Copyright (C) International Association of African Researchers and Reviewers, 2006-2017: www.afrrevjo.net.

Indexed African Journals Online: www.ajol.info 
resort to excessive religiosity to avoid or ward off his or her problems or to cover up his or her weaknesses and inabilities. It serves as an escape or defense mechanism because they tend to dodge reality. This practice has a great negative effect on workers' performance and national development.

\section{- Underdevelopment}

Underdevelopment is a bane to progress in Nigerian organisations. As far as invention and innovation is far from Nigeria, organisations in Nigeria will continue to have problems in the areas of workers' performance with negative effect on national development.

\section{- Dependence on other races}

Nigerians psychologically depend on the developed nations for help in solving their problems, and for the satisfaction of most of their needs. Dependency is a sign of psychological and intellectual weakness which dominates Nigerian organisations and this affects workers' performance and national development.

\section{- Uninspiring weak leadership}

Workers' performance or effectiveness in Nigerian organisation is difficult to achieve because she lacks the type of inspiring patriotic leadership. Our national leaders are characterised by the following weaknesses.

1. Lack of freedom and inability of our leaders to act and to perform without fearing or consulting her Western creditors and former colonial master.

2. Inability to effectively enforce beneficial laws, rules and standards.

3. Lack of resolute patriotic character that can mobilise the citizens to develop love for their country.

4. Failure to develop and implement practical programmes for self-reliance, local production, agriculture and indigenisation.

5. Failure to inspire in the people through examples and personal demonstrations the virtues of trust, honesty, dignity, self-sacrifice, seriousness, handwork, integrity and self-reliance.

Leaders that lack these characteristics are not motivating leaders, Workers' performance in organisations which such leaders control cannot function well and such a nation will never develop. Despite all the aforementioned shortcomings, this paper was able to proffer strategies for solving the problems as indicated below.

\section{Strategies for Solving the Problems Caused by Perceived Negative Foreign Factors}

In order to solve the multifarious factors affecting workers' performance in Nigeria, one has to trace the root of these problems and proffer some strategies to solve them accordingly. Some of these strategies are discussed below.

\section{(a) Scientific ethos}

Chinweizu (1984a) has clearly defined scientific ethos as consisting of being critical, speculative, problem-solving oriented and highly anti-authoritarian and nondifferential to status. Thus, when a society is permeated by such an ethos, its citizens are disposed to approach whatever they do in a critical, speculative, problem solving

Copyright (C) International Association of African Researchers and Reviewers, 2006-2017: www.afrrevjo.net.

Indexed African Journals Online: www.ajol.info 
and democratic spirit. The citizens will devote their attention to how their cravings could be satisfied through their own efforts. Nigeria and Nigerians are thereby encouraged to imbibe mentality of scientific ethos in order to achieve national development.

\section{(b) Establishment of technological development board}

Since Nigerians are familiar with different brands of technologies in the World, the functions of the Board when established are not only to undertake technological inventions but to also develop or modify the existing technologies to suit the country's conditions, to accommodate her peculiarities, and to encourage local initiatives or efforts to finance commercial production of the appropriate local technology and to locate local resources nationwide.

\section{(c) Getting out of debt-trap peonage}

Chinweizu (1984) suggested many years ago that Nigeria and her organisations cannot be effective until she frees herself from the debt-trap peonage into which she has been imprisoned and is heavily being guided. For Nigeria, Chinweizu recommended a selfadministered programme of cure which will require us to end our squandamania, avoid taking new loans, discourage importation and eradicate or reduce our debts to a barest minimum. He suggests that the IMF loan and its externally administered policies be totally discouraged and possibly stopped. According to him, to get cured of the squandamania and import mania which turn us into loan addicts, we must work out the details of a schedule of total withdrawal; have the discipline, the resolve and the determination which comes from a conviction that a difficult course of action is in our best interest; we have to mobilise our spirit of sacrifice for national salvation and organise ourselves for the long hard march to national development. His suggestions of over thirty years ago are still much relevant in today's Nigeria.

\section{(d) Management by objectives and self-control}

This strategy was first developed by Drucker (1954). It operates by clearly stating the specific goals of the organisation. It is the principle of management that gives full scope to individual strength and responsibility and at the same time gives common direction of vision and effort, establish team work and harmonise the goals of the individual with the common needs. Strict adherence to this strategy will surely lead to national development

\section{(e) Revolutions}

The assertion of Hall (1977) and his fellow Western scholars that economic independence is impossible for underdeveloped countries should serve as an important cue for Nigeria. Hall however follows this assertion by saying that the only way an underdeveloped country can achieve economic independence is by "national revolution". Many Nigerians in the past have also advocated for such revolution. For instance, Benedict (1984) opined that the indigenisation decree should be enforced to the letter. Oyebola (1976) called for self and mental revolution, Nwankwo (1984) called for psychological revolution. In the recent time, many Nigerians have consistently called for patriotic revolution, cultural revolution, language revolution, agricultural revolution, educational revolution, intellectual revolution, scientific and technological revolution; and industrial revolution. Currently, the revolutionary slogan

Copyright $\odot$ International Association of African Researchers and Reviewers, 2006-2017: www.afrrevjo.net.

Indexed African Journals Online: www.ajol.info 
in Nigeria includes: restructuring, reconfiguring, resource control, devolution of power, true federalism and self-determination. A radical change from the overwhelming social decadence and neo-colonial situation by the citizens of Nigeria would lead to a revolutionary process whose ultimate goal is to develop a system free of corruption and injustice, where completely new breed of selfless leaders shall manage the country's national affairs in the best interest of both the rich and the poor.

\section{(f) Acquiring of psychological power}

Psychological power is the most dynamic and most influential of all the acquired psychological factors in the whole process of individual or national development. This is the ability of the individual or group to learn or master complex details, perform challenging cognitive tasks and accomplish self-determined goals (Eze, 1984). In essence, it is the sum total of the individual's cognitive, intellectual and artistic insight that leads to a consistent super excitation of the intellectual forces necessary to create inquiring and enabling environment for national development. Sources of psychological power according to Eze (1984) include:

- A progressive scientific culture.

- A scientific national language.

- A civilised indigenous religion.

- Total independence and freedom from external influence and domination.

- A stimulating and encouraging environment with regards to intellectual, scientific and technological pursuit.

- Practical educational system that will encourage critical attitude, the development of abstract thinking, and creative inventive aptitudes.

\section{Conclusion}

In conclusion, Nigerians should accept that they are yet to catch up with the fastchanging world in which the developed countries have not only built modern nations but have adapted tools and technology to conquer time and space. Nigeria must at this stage, pause a little and ask herself as a nation, why the failure in her organisation? Why are Nigerians unable to make valid contributions to world technological civilisation and advancement considered the common heritage of all mankind? Why are we unable to achieve a significant success in the area of workers' performance in our organisations? Every right-thinking person must be struck by our negativity, opportunism, parochialism and shameless bankrupt leaders and leadership styles which have constituted a barrier to our national development. It will be good to end this paper with a quote from Kukah (2017) on the current situation in Nigeria: "Nigerian educational systems have surprising outcomes.

The smartest students get admitted to Medical and Engineering schools and pass with First Class. The Second-Class students get MBA and LLB certificates to manage the First-Class students. The Third-Class students enter politics and rule both the First Class and Second-Class students. The Failures enter the underworld of crime and control the politicians and business men and women. And the best of all, those who did not attend school become Prophets and Imams and everyone including First Class, Second Class, Third Class graduates and the Failures follow them. What a paradox of life! This can only happen in Nigeria where corruption is the order of the day" This scenario as painted by Kukah, is antithetical to national development and may not be

Copyright () International Association of African Researchers and Reviewers, 2006-2017: www.afrevjo.net.

Indexed African Journals Online: www.ajol.info 
unconnected with the perceived negative influence of foreign factors on Nigeria and Nigerians.

\section{References}

Benedict, A. (1984). Reviving Nigeria's acting economy. Business Times, June 4, pp.12-13.

Chinweizu, (1984). Averting debt trap peonage. A paper presented at the UBA Conference on Foreign Debt and Nigeria's Economic Development, at Victoria Island, Lagos, Nigeria

Chinweizu, (1984a). The scientific ethos and the modern nation states. The Guardian Newspaper, Nigeria, June 24, p.10.

Drucker, P. F. (1954). The practice of management. New York: Harper and Row.

Eze, N, (1981). Psychological analysis of the major obstacles to Nigerian industrialisation and self-adequacy". In Bakare, C. G. M. \& Durojaiye, M. O. A. (Eds.), Proceedings of the 1981 Conference of NPA, University of Jos, Nigeria

Eze, N. (1984). Organisational effectiveness in Nigeria. An Industrial Organisational Psychological Monograph University of Lagos, Nigeria

Fanon, F. (1963). The wretched of the earth. In C. S. A. Ogbuagu, Nigeria: Development policies and programmes. Calabar, Nigeria: University of Calabar Press.

Gboyega, O. (2003). Democracy and development: The imperative of local governance. An Inaugural Lecture, University of Ibadan, Nigeria, pp. 6-7

Hall, R. H. (1977). Organisations: Structure and Process. New Jersey: Englewood Cliffs, Prentice-Hill, Inc.

John, H.W (1972). The restless organisation, New Jersey: Wiley International Publication, Co.

Kukah, M.H. (2017). Quote on the current situation in Nigeria by the Catholic Bishop of Sokoto Diocese, Sokoto, Nigeria. Retrieved from Social Media: WhatsAppJune, 2017.

Lawal, T. \& Abe, O. (2011). National development in Nigeria. Issues, challenges and prospects, Journal of Public Administration and Policy Research, 3 (9) 237241

Mitchell, R.T. (1967). People in organisation: An introduction to organisational behaviour (2nd Ed), NY: McGraw-Hill.

Nwankwo, A.O. (1984). Nigeria and the quest for economic independence" Keynote Lecture Delivered at the Nigerian Economics Students Association, Economic Week, Ahmadu Bello University, Zaria, Nigeria.

Ogbuagu, C. S. A. (1995). Nigeria: Development policies and programmes. Calabar, Nigeria: University of Calabar Press.

Copyright $\odot$ International Association of African Researchers and Reviewers, 2006-2017: www.afrrevjo.net.

Indexed African Journals Online: www.ajol.info 
Ogunkuade, I. M (2016). The perspective of workplace behaviour. Ife PsychologIA, $24,179-181$

Okogie, A. O. (2017). The upbraiding of Pentecostal churches: Interview granted by Archbishop Emeritus of the Catholic Archdiocese of Lagos, on the situation of religious practice in Nigeria: Retrieved from Social Media: WhatsApp - posted by Okupa, J. on 14 Oct., 2017.

Oyebola, A. (1976). Blackman's dilemma. Ibadan, Nigeria: Board Publications Limited.

Rodney, W. (1972). How Europe Underdeveloped Africa. London: Bogle-L'Ouverture Publications.

Schein, E A. (1965). Organisational psychology, 3rd Ed, New Jersey: Prentice-Hall.

Stanley, V. (1959). Industrial administration. McGraw-Hill Book Co, Inc. pp. 1051360.

UNESCO (2015). Literacy statistics metadata information table. UNESCO Institute of Statistics. Retrieved from unesdoc.unesco.org-October, 2017

Copyright $\odot$ International Association of African Researchers and Reviewers, 2006-2017: www.afrrevjo.net.

Indexed African Journals Online: www.ajol.info 